

DEN NORSKE LEGEFORENING

\title{
Ikke stikk fingrene i stikkontakten
}

\section{LEDER}

\section{CHRISTINA ELISABETH BRUDVIK}

christina.brudvik@uib.no

Christina Elisabeth Brudvik er spesialist i allmennmedisin og professor ved Klinisk institutt 1, Universitetet i Bergen, tilknyttet Skadepoliklinikken i Helse Bergen. Hun arbeider som fastlege ved Fana legekontor og vaktlege ved Bergen legevakt.

Forfatteren har fylt ut ICMJE-skjemaet og oppgir ingen interessekonflikter.

\section{Elektriske støt bør unngås, selv om støt med lavspenning ikke er så farlig som man lenge har trodd.}

Det er vanskelig å få plass til både små og store fingre i stikkontakten. Heller ikke en strikkepinne er lenger lett å stikke inn etter at de nye stikkontaktene ble barnesikret med spesielle barrierer. Det går an hvis man bruker to strikkepinner samtidig, men selv da vil oftest jordfeilbryteren slå av strømmen slik at du ikke merker noe. Hvis derimot jordfeilbryteren ikke slår inn, vil fingrene dine krampe seg rundt strikkepinnene i hver hånd og lede strømmen gjennom brystkassen. Kroppen din blir da en del av strømkretsen der strømstyrke, eksponeringstid og strømvei avgjør grad og lokalisasjon av skade på hud, hjerte, nervebaner og muskulatur i brystkasse og armer.

I dag skilles det mellom lavspenning og høyspenning i et elektrisk anlegg. International Electrotechnical Commission (IEC) og Norsk elektroteknisk komité (NEK) definerer lavspenning som opp til og med 1 ooo volt (V) vekselspenning eller 1500 volt likespenning (1). I Norge benyttes stikkontakter med 230 volt spenning i vanlige hus. I andre europeiske land brukes en linjespenning på 400 volt, noe også Norge legger til rette for i nye utbygginger. Det er denne spenningen som kreves for å lade el-biler.

Ved høyspentulykker, dvs. ved > 1 ooo volt, fra lynnedslag eller høyspentkabler blir store energimengder overført i brøkdelen av et sekund. Strømgjennomgangen ved lavspentulykker må vare minst et par sekunder for å gi alvorlige vevsskader, mens hjertearytmier kan oppstå raskt (1). Overflatiske brannskader i hud kan skjule større brannskader i bløtvev og bein. Kramper, muskelrupturer, lammelser, muskellosjesyndrom og nyresvikt grunnet stor muskelskade (rabdomyolyse) er andre komplikasjoner som krever behandling (1-4).

«Inntil nylig ble også innleggelse anbefalt ved strømulykker etter lavspenning» 
Hvert år rammes rundt 3 ooo yrkesaktive av strømskader i Norge (4). Elektrikere er mest utsatt, særlig ved arbeid med sikringsskap. Førstehjelp gis ved å skru av strømmen, helst hovedstrømbryteren, og fjerne den skadete fra strømkilden ved å trekke i tørre klær. Ved høyvoltskader kan dette være risikofylt selv om man er godt isolert med gummihansker og gummistøvler $(5, \underline{6})$.

Pasienter utsatt for høyspenning trenger øyeblikkelig livreddende førstehjelp og sykehusinnleggelse. Inntil nylig ble også innleggelse anbefalt ved strømulykker etter lavspenning (2). Sykehusene ga imidlertid tilbakemelding om at dette ville bli for ressurskrevende og at tilstrekkelig medisinsk hjelp kunne gis på et lavere behandlingsnivå, som via medisinsk nødtelefon, hos fastlege eller på legevakt. Anbefalingene ble derfor i samråd med Statens arbeidsmiljøinstitutt (STAMI) endret til at man burde oppsøke «medisinsk hjelp» hvis man hadde vært utsatt for strøm gjennom hjerteregion/overkropp, vært bevisstløs, omtåket eller uvel etter ulykken, hadde brannskader eller tegn på lammelser, balanseproblemer eller nummenhet (4-ㅡㅁ).

Elektrikerbransjen fryktet lenge at denne lempingen på kravet om sykehusinnleggelse ville medføre dårligere medisinsk oppfølging. Ettersom dagens interkommunale legevakter, kommunale øyeblikkelig hjelp-døgnenheter og mottaksavdelinger på sykehus har mulighet for observasjon med EKG-monitorering og laboratorietjenester, er dette neppe tilfellet.

Svendsen og medarbeidere publiserer nå i Tidsskriftet en retrospektiv gjennomgang av 210 pasienter med strømskader fra lavspenning (7.). Kun få barn, eldre og pasienter med komorbiditet var inkludert, men studien bekrefter likevel at risikoen for komplikasjoner er svært lav. Normale eller uforandrete EKG-utslag i tidlig fase predikerte fravær av senere arytmier. Antallet tilfeldige EKG-funn var på nivå med det vi ser ved screening av friske, og endringene gikk spontant tilbake. Kreatininkinasenivået i serum nådde aldri grenseverdiene for rabdomyolyse ( 10 ooo $\mathrm{U} / \mathrm{L})$ med behov for forsert diurese $(3, \underline{8})$ og tilsvarte det som kan observeres etter kraftigere styrketrening $(\underline{8})$.

I en travel klinisk hverdag utfører vi mange unødvendige rutinemessige utredninger av frykt for å overse noe (9). Svendsen og medarbeideres studie er derfor viktig. Sammen med tidligere oversiktsartikler og evidensbaserte anbefalinger $(\underline{\mathbf{1}}, \underline{2})$ gjør deres artikkel oss tryggere på at relativt enkle undersøkelser og korte observasjoner utenfor sykehus er tilstrekkelig hos de fleste pasienter utsatt for lavspenning. Som alltid er likevel forebygging det beste, og det er fortsatt viktig å unngå elektrisk støt.

LITTERATUR

1. Waldmann V, Narayanan K, Combes $\mathrm{N}$ et al. Electrical cardiac injuries: current concepts and management. Eur Heart J 2018; 39: 1459-65. [PubMed][CrossRef]

2. Veiersted KB, Goffeng LO, Moian R et al. Akutte og kroniske skader etter stromulykker. Tidsskr Nor Lægeforen 2003; 123: 2453-6. [PubMed]

3. Goffeng LO, Stormoen DR, Veiersted KB. Elektrikerlærling skadet av strømgjennomgang. Tidsskr Nor Legeforen 2018; 138. doi:10.4045/tidsskr.17.0613. [PubMed][CrossRef]

4. Goffeng LO, Veiersted KB, Moian R et al. Forekomst og forebygging av strømulykker i arbeidslivet. Tidsskr Nor Lægeforen 2003; 123: 2457-8. [PubMed]

5. Statens arbeidsmiljøinstitutt. Strømskader. https://stami.no/vare-tjenester/stromskader/ Lest 8.12.2021.

6. Norsk elektronisk legemiddelhåndbok. Strømulykker. https://arbeidsmedisin.legehandboka.no/handboken/kliniske-kapitler/arbeidsrelatertesykdommer/sykdommer-og-plager/stromulykker/\#anbefalinger-for-leger-i-prim-rhelsetjenesten Lest 8.12.2021.

7. Svendsen TB, Bærheim D, Dale J et al. Pasienter med strømgjennomgang fra lavspenning henvist til et akuttmottak. Tidsskr Nor Legeforen 2022;142. doi: 10.4045/tidsskr.21.0415. [CrossRef] 
8. Clarkson PM, Kearns AK, Rouzier P et al. Serum creatine kinase levels and renal function measures in exertional muscle damage. Med Sci Sports Exerc 2006; 38: 623-7. [PubMed][CrossRef]

9. Den norske legeforening. For mye, for lite eller akkurat passe? https://www.legeforeningen.no/omoss/rapporter/for-mye-for-lite-eller-akkurat-passe/ Lest 8.12.2021.

Publisert: 10. januar 2022. Tidsskr Nor Legeforen. DOI: 10.4045/tidsskr.21.0845

(C) Tidsskrift for Den norske legeforening 2023. Lastet ned fra tidsskriftet.no 26. april 2023. 